\title{
A Qualitative View of Drug Use Behaviors of Mexican Male Injection Drug Users Deported from the United States
}

\author{
Victoria D. Ojeda, Angela M. Robertson, Sarah P. Hiller, \\ Remedios Lozada, Wayne Cornelius, Lawrence A. Palinkas, \\ Carlos Magis-Rodriguez, and Steffanie A. Strathdee
}

\begin{abstract}
Deportees are a bidden yet highly vulnerable and numerous population. Significantly, little data exists about the substance use and deportation experiences of Mexicans deported from the United States. This pilot qualitative study describes illicit drug use behaviors among 24 Mexico-born male injection drug users (IDUs), $\geq 18$ years old, residing in Tijuana, Mexico who self-identified as deportees from the United States. Inperson interviews were conducted in Tijuana, Mexico in 2008. Content analysis of interview transcripts identified major themes in participants' experiences. Few participants had personal or family exposures to illicit drugs prior to their first U.S. migration. Participants reported numerous deportations. Social (i.e., friends/family, post-migration stressors) and environmental factors (e.g., drug availability) were perceived to contribute to substance use initiation in the U.S. Drugs consumed in the United States included marijuana, heroin, cocaine, methamphetamine, and crack. More than half of men were IDUs prior to deportation. Addiction and justice system experiences reportedly contributed to deportation. After deportation, several men injected new drugs, primarily heroin or methamphetamine, or a combination of both drugs. Many men perceived an increase in their substance use after deportation and reported shame and loss of familial social and economic support. Early intervention is needed to stem illicit drug use in Mexican migrant youths. Binational cooperation around migrant health issues is warranted. Migrant-oriented programs may expand components that address mental health and drug use behaviors in an effort to reduce transmission of blood-borne infections. Special considerations are merited for substance users in correctional systems in the United States and Mexico, as well as substance users in United States immigration detention centers. The health status and health behaviors of deportees are likely to impact receiving Mexican communities. Programs that address health, social, and economic issues may aid deportees in resettling in Mexico.
\end{abstract}

KEYWORDS Substance use, Deportation, Migration, Mexico, Qualitative research

\section{INTRODUCTION}

Statistics on illicit drug use among Mexican migrants to the United States display two notable characteristics, reflecting conditions in both sending and receiving coun-

Ojeda, Robertson, Hiller, Cornelius, and Strathdee are with the Division of Global Public Health, UCSD School of Medicine, University of California, San Diego, La Jolla, CA, USA; Lozada is with the Patronato ProCOMUSIDA, A.C., Tijuana, Mexico; Palinkas is with the School of Social Work, University of Southern California, Los Angeles, CA, USA; Magis-Rodriguez is with the Centro Nacional para la Prevención y Control del VIH/SIDA e ITS, Mexico City, Mexico.

Correspondence: Victoria D. Ojeda, Division of Global Public Health, UCSD School of Medicine, University of California, San Diego, 10111 N. Torrey Pines Road, La Jolla, CA 92093-0507, USA. (E-mail: vojeda@ucsd.edu) 
tries. ${ }^{1-3}$ First, illicit drug use among Mexican migrants is lower than among U.S.-born Mexicans or non-Latino whites. ${ }^{4}$ Second, Mexican migrants' consumption of illicit drugs is substantially greater than that of persons in Mexico. ${ }^{1,5,6}$ For example, one study conducted between 2004 and 2005 examined cocaine and methamphetamine use by Mexican migrants in California and found that 21\% of males (i.e., 209 of 985 respondents) consumed either drug. ${ }^{5}$ In contrast, the Encuesta Nacional de Adicciones [2008 Mexico National Drug Addictions Survey] found that overall, only 5.7\% of persons ages 12-65 have ever consumed any illicit drug, fewer than 3\% of respondents have ever consumed cocaine, and $<1 \%$ have ever consumed heroin. ${ }^{1}$

While Mexico has historically reported low levels of drug use, national lifetime prevalence rates of substance use are rising $(5.0 \%$ in 2002 to $5.7 \%$ in 2008$) .^{1,7}$ Northern Mexican states report levels of illicit drug use above the national mean. The state of Baja California ranks third in illegal drug use $(9.3 \%) ;^{1}$ notably, it lies on drug trafficking routes of cocaine, methamphetamine, and heroin. ${ }^{8}$ Drug use affects males disproportionately: in Baja California, $13.9 \%$ of males reported any illicit drug use during their lifetime (vs. $4.6 \%$ of women). Injection drug use is rising in Tijuana, Baja California, ${ }^{9}$ and many injection drug users (IDUs) engage in polydrug use. Substance use is associated with higher rates of sexually transmitted and bloodborne infections due to engagement in risky sexual and drug use behaviors. ${ }^{10}$ The emerging HIV epidemic on the Mexico-U.S. border is fueled by the overlapping influences of injection drug use, sex work, poverty, and migration. ${ }^{11-13}$

Deportation, a type of forced migration, may be associated with additional social and economic vulnerabilities ${ }^{14,15}$ that may increase the risk of HIV. Our binational research team recently found that $42 \%$ of adult male IDUs living in Tijuana, Mexico, had been deported from the United States; moreover, deportation from the United States was independently associated with a fourfold increased odds of HIV infection among male IDUs. ${ }^{13}$ Unfortunately, we could not determine whether HIV transmission occurred in the United States or Mexico since the study did not collect migration and deportation histories. However, findings from a seroprevalence study of clients in Los Angeles' public sexually transmitted infections clinics suggest that HIV infection in immigrants, including Latino immigrants, may occur in the United States ${ }^{16}$

Mexican-origin persons account for nearly two thirds of all Latinos in the United States. ${ }^{17}$ It is estimated that $\geq 50 \%$ of unauthorized immigrants in the United States are of Mexican descent. ${ }^{18,19}$ Unauthorized immigrants are vulnerable to being apprehended and expelled by immigration officials. Since 1990, 1 million persons are apprehended annually by U.S. immigration officials. The majority of detainees are returned to their birth country. Mexican nationals account for the majority of deportable and repatriated persons. For example, in 2008, 359,000 persons were expelled from the United States based on an order of removal; of these, 247,000 were Mexican nationals $(\sim 69 \%)$. $^{20}$

Research on the health behaviors of persons expelled from the United States is noticeably absent from the public health research literature even though deportees are a sizeable population that reports binational relationships. ${ }^{14}$ Notably, few studies have elucidated the context surrounding Mexican migrants' drug use behaviors pre- and post-migration. Limited research finds that Mexican migrants were exposed to illicit substances during migration, in the United States and border communities by friends, family, or smugglers. ${ }^{21}$ Significantly, the lack of data on the climates under which drug use occurs limits our knowledge of and ability to intervene on the diverse social, economic, and environmental factors that may contribute to these striking differences in substance use behaviors among Mexican 
migrants on both sides of the United States-Mexico border. In this pilot study, we used qualitative data to describe illicit drug use behaviors in diverse settings among male IDUs residing in Tijuana, Mexico who self-identified as deportees.

\section{METHODS}

\section{Sampling and Data Collection}

Between October and November 2008, we recruited male IDUs reporting a history of deportation from the United States from a prospective observational study of behavioral and contextual factors associated with HIV and related comorbidities among IDUs. The prospective study is based in Tijuana, Mexico and used respondent-driven sampling, ${ }^{22}$ as described elsewhere. ${ }^{13,23}$ To identify potential participants, we first generated a list of IDUs from the prospective study who previously reported a history of deportation from the United States ( $n=377$ males). Participants were recruited based on their availability and exhibited a wide range of deportations (minimum, 1; maximum, $\sim 25$ ). Our study is based on data obtained from 24 interviews; we terminated participant recruitment when saturation of themes was obtained in qualitative interviews.

Potential participants were first screened to confirm their eligibility. Inclusion criteria for this qualitative study included: being $\geq 18$ years, born in Mexico, residing in Tijuana, a history of deportation from the United States, and being an IDU. Eligible individuals were invited to participate and underwent voluntary and informed consent. The study protocols were approved by Institutional Review Boards at the University of California, San Diego and Tijuana General Hospital.

In-depth semi-structured qualitative interviews were conducted by bilingual interviewers under the direction of the first author at the prospective study's field office site, located in Tijuana's zona roja (red light district). Interviews were conducted in Spanish $(n=20)$ or English $(n=4)$, based on the participant's preference, and lasted between 1 and 2 hour. Examples of interview questions included: "Before migrating to the U.S., were you already using drugs?" and "Tell me about your drug use in the U. S.," and "Tell me about your drug use in Tijuana since being deported." Participants frequently had extensive deportation histories, thus, we asked participants to focus on their most recent deportation. Participants were reimbursed \$20 (U.S.) for their time. Interviews were digitally recorded; audio files were anonymous and identified by alphanumeric codes assigned by the prospective study. Interview transcripts were not translated, thus preserving the original connotations and meanings of the participants' language, which was often bilingual and contained local slang specific to the drug subculture in the United States-Mexico border region.

\section{Analyses of Qualitative Data}

All transcribed interviews were uploaded into the qualitative data analysis software, ATLAS.ti. ${ }^{24}$ An initial coding scheme of key concepts and categories was created by two research assistants (RAs), who read several cross sections of interviews. The principal investigator and RAs, all of whom are bilingual, independently applied these codes to five interviews in order to refine and create nuanced codes. To ensure that coders shared the same understanding, sections of five additional interviews were coded and discrepancies among them were discussed and resolved amongst the research team. ${ }^{25}$ Analysis followed a general inductive approach where investigators focused on generating themes and identifying relationships among themes. ${ }^{26}$ If new 
codes emerged, the coding scheme was changed and the transcripts were re-read and coded according to the new structure. When saturation of themes was achieved (i.e., the lack of new emergent codes), we terminated recruitment and interviews, as major themes had been identified. We have provided the English translations of Spanish language quotes for brevity and clarity; quotes in Spanish are available upon request.

\section{RESULTS}

\section{Participant Characteristics}

Interviews were conducted with 24 men who identified as deportees. Sociodemographic characteristics, based on qualitative interviews, are provided in Table 1. Male injection drug using deportees averaged 37 years old at the time of interview and originated from throughout Mexico. Northern states, such as Sonora and Sinaloa, and traditional migrant-sending states (e.g., Jalisco and Zacatecas) were represented. On average, men undertook their first trip to the United States prior to their 18th birthday and had family or friends already residing in the United States $(84 \%)$. All participants resided in California during the time they spent in the U.S. Half of the men specifically mentioned migrating to improve their economic situation. Men reported living in approximately 2 United States cities and an average of 5 deportations. The most recent deportation occurred $\sim 7$ years prior to the interview. Fewer than half of participants remained in contact with family members following their deportation. More than half of the participants intended to return to the United States in the future; nearly half of the men reported being banned from re-entry into the United States or anticipated being imprisoned if detected in the United States.

\section{Pre-Migration Drug Use}

Male deportees' exposure to drugs in Mexico prior to ever migrating to the United States varied greatly. One fifth of deportees reported never consuming any illicit drugs prior to their first U.S. migration, as one participant described:

I was even unfamiliar with pot (i.e., marijuana), I did not smoke, when I started [using drugs], it was in the United States. (Age 42, from Michoacán, first migrated at age 14)

\section{Another participant noted:}

There [in the U.S.], I learned about drugs, I learned that vice, and I became an addict. (Age 47, from Veracruz; migrated at age 17)

Conversely, about one half $(n=13)$ of participants reported consuming some combination of marijuana, inhalants, or alcohol prior to emigrating from Mexico to the United States for the first time. A minority of deportees tried drugs such as heroin or cocaine in Mexico while observing family or drug users in their hometowns or while journeying through Tijuana to the United States.

\section{Drug Use in the U.S.}

All deportees consumed illicit drugs in the U.S., though the contexts surrounding their initiation into substance use widely differed. For example, drug use frequently occurred at social events including weddings, neighborhood parties, quinceañeras 
TABLE 1 Selected sociodemographic characteristics at the time of interview; Mexican male injection drug users who reported ever being deported from the U.S., Tijuana, Baja California, Mexico, 2008

\begin{tabular}{|c|c|c|}
\hline & $\begin{array}{l}\text { Number of respondents } \\
\text { ( } n=24 \text { possible) }\end{array}$ & $\%$ or frequency (SD) \\
\hline Age (at time of interview, in years) & 24 & $36.9(7.3)$ \\
\hline \multicolumn{3}{|l|}{ Mexico state of origin } \\
\hline Sonora & 5 & $21 \%$ \\
\hline Jalisco & 4 & $17 \%$ \\
\hline Sinaloa & 4 & $17 \%$ \\
\hline Federal District & 2 & $8 \%$ \\
\hline Veracruz & 2 & $8 \%$ \\
\hline Zacatecas & 2 & $8 \%$ \\
\hline Michoacán & 1 & $4 \%$ \\
\hline Chihuahua & 1 & $4 \%$ \\
\hline Nayarit & 1 & $4 \%$ \\
\hline Guerrero & 1 & $4 \%$ \\
\hline Morelos & 1 & $4 \%$ \\
\hline \multicolumn{3}{|l|}{ Migration history } \\
\hline Mean age at first migration in years (SD) & 19 & $17.68(8.76)$ \\
\hline Mean number of U.S. cities lived in & 24 & $2.25(2.17)$ \\
\hline Had family/friends in the U.S. before migration & 19 & $84.2 \%$ \\
\hline $\begin{array}{l}\text { Established deportee ( } \geq 5 \text { years residing } \\
\text { in Tijuana) }\end{array}$ & 15 & $62.5 \%$ \\
\hline \multicolumn{3}{|l|}{ Migration objectives $^{a}$} \\
\hline Work/money & 13 & $54 \%$ \\
\hline Wanted to see the United States & 5 & $21 \%$ \\
\hline Leaving home/running away & 4 & $17 \%$ \\
\hline Personal growth/feeling grown-up & 3 & $13 \%$ \\
\hline Taken to U.S. by family as child & 2 & $8 \%$ \\
\hline Running away from the law in Mexico & 1 & $4 \%$ \\
\hline \multicolumn{3}{|l|}{ Deportation history } \\
\hline Mean number of times deported ${ }^{\mathrm{b}}$ & 24 & $5.46(5.31)$ \\
\hline $\begin{array}{l}\text { Most recent deportation (mean number } \\
\text { of years ago) }\end{array}$ & 24 & $7.30(4.52)$ \\
\hline $\begin{array}{l}\text { Maintain contact with family members } \\
\text { post-deportation }\end{array}$ & 16 & $44 \%$ \\
\hline $\begin{array}{l}\text { Reported being banned from re-entry into } \\
\text { United States/will face imprisonment }\end{array}$ & 11 & $46 \%$ \\
\hline $\begin{array}{l}\text { Intend to return to the United States } \\
\text { in the future }\end{array}$ & 20 & $83 \%$ \\
\hline \multicolumn{3}{|l|}{ U.S. states lived in $^{\mathrm{a}}$} \\
\hline California & 24 & $100 \%$ \\
\hline Washington & 2 & $8 \%$ \\
\hline Oregon & 1 & $4 \%$ \\
\hline Washington DC & 1 & $4 \%$ \\
\hline Texas & 1 & $4 \%$ \\
\hline Nevada & 1 & $4 \%$ \\
\hline New Mexico & 1 & $4 \%$ \\
\hline
\end{tabular}

Data are obtained from qualitative interviews

${ }^{a} n$ may exceed 24 since some respondents provided more than one response

${ }^{\mathrm{b}}$ Respondents may have been deported more than once 
(debutante parties for girls celebrating their 15th birthday) or at bars or nightclubs with friends or family members $(n=16)$. Significantly, ten men specifically indicated that friends and acquaintances facilitated their initiation into drug use in the United States. One respondent remarked:

My first contact in the U.S. was during the weekends, when I often went to the parties, to dances, and my first contact was-I had a friend from Zacatecas, and there I began to use crystal [methamphetamine], and to learn about it through him. (Age 36, from Zacatecas, migrated at age 15)

Additionally, four participants identified female romantic partners as aiding their initiation into illicit drug use. Many men reported consuming drugs during sexual encounters.

Numerous men reported being active within the labor market before engaging in drug use, holding jobs in construction, factories, supermarkets, and landscaping, among others. Employment in the formal economy was reportedly interrupted by increased drug use, selling drugs, incarceration, or deportation. Although employment-related reasons for drug use were less frequently cited as reasons for initially consuming drugs in the United States, several men reported that their co-workers shared drugs; others used drugs to cope with work conditions (e.g., hours, type of work). One participant recalled:

...Sometimes we would work until very late and there came a point when I was feeling tired and I began using drugs, little by little.... (Age 31, from Sonora, migrated at age 22)

Less frequently, men associated other conditions (e.g., heavy drinking, prior consumption of illicit drugs, gang involvement, drug selling, or transporting) with commencing drug use in the United States. Several men reported initiating drug use to cope with family problems or depression or loneliness resulting from separation from friends and family in Mexico. The drugs most frequently consumed were marijuana, heroin, cocaine, methamphetamine, and crack $(n=12,12,11,9$, and 6 , respectively). Other drugs (e.g., PCP, acid, Valium) were consumed infrequently though also mentioned in the context of social events or parties. Alcohol use was mentioned by one quarter of participants, but was likely under-reported as we did not specifically probe for alcohol consumption.

\section{Injecting Drugs in the United States}

Injection drug use behaviors in the United States were commonly reported by male deportees. Nearly one half of men reported regularly injecting heroin, cocaine, or methamphetamine during at least one stay in the United States. Men reported injecting drugs due to curiosity, seeking a stronger effect, and less painful or harmful method of administration than could be obtained by smoking or snorting the substances or because their social network (i.e., family, friends, girlfriends, or sex partners) included IDUs. Injection practices varied greatly; several men commented that they did not share injection equipment:

There [in the U.S] I always bought a bunch, and never needed any [needles], always had needles, always had new injection equipment... People that were there, they would bring and exchange syringes, they get a good price and there are people who come to sell them [syringes] by the bunch, 60 or 70 needles. (Age 26, from Sonora, regular crack and heroin user while living in Los Angeles) 
Conversely, several men described unsafe injection practices (e.g., sharing injection equipment, injecting with groups of people at social events).

\section{Criminal Justice System and Substance Use Experiences}

The majority of male deportees were in the U.S. criminal justice system; others reported more than one detention in U.S. immigration facilities due to immigrationrelated violations. During these periods, nearly half of men reported smoking marijuana. However, smoking or injecting other drugs such as methamphetamine or heroin was infrequently reported. Deportees $(n=12)$ who did not consume illicit drugs during any detention period experienced withdrawal or viewed that period as an opportunity to "get clean." Others reported that drugs were expensive or difficult to access. Drug use while in jail or detention was sometimes considered risky due to adverse physical reactions. One 29-year-old deportee from Chihuahua described avoiding drug use while in prison in Anaheim during his mid-20s:

I could use crystal [methamphetamine] because it was available, but I did not want to use it anymore because crystal damaged me, my nerves, that is, it affected me greatly-I did not have panic attacks or anything, I was not aggressive, I simply made movements that I did not want to make, I did not talk to myself or anything like that, but I made movements that my brain did not send-like moving my hands like this, as if I had a tic, and it was because my nerves and my senses were damaged, they were destroyed, it was like that for 15 days almost without any sleep.

\section{Drug Use and Deportation}

Male deportees frequently felt that their drug use behaviors or involvement in the drug economy in the United States contributed to their deportation. Feelings of rejection by U.S. society were identified by some participants. One deportee interpreted his deportation in the following manner:

...They must think that, you know, like, I'm bad out there for society, criminal for being, for taking something like that you know, that's why I got deported. (age 26, from Guerrero, resided in Southern California; migrated to U.S. at age 1)

Men's increased drug use required them to supplement their incomes from jobs in the formal economy with drug-related funds. Friends or fellow gang members encouraged deportees to sell or transport drugs. Eight men reported being arrested for selling, transporting, or possessing drugs; 7 were arrested because of their drug use (i.e., being under the influence of drugs in public).

Several men described their increased drug use as contributing to a poor quality of life, greater participation in illegal activities, and growing criminal records. Various participants reported that escalating addiction and legal problems ultimately increased their risk of and contributed to their deportation. One participant remarked:

I used heroin and had to steal in order to support my habit and one of those times, they caught me and put me in jail and I stayed there for 2 years and at the end of that period, they deported me to Tijuana. (age 39, from Mexico's Federal District, resided in Los Angeles) 


\section{Perceived Changes in Drug Use Post-Deportation}

Deportees perceived changes in their drug use following deportation. Although more than half of deportees were IDUs prior to being deported to Mexico, several men described injecting new drugs, primarily heroin or methamphetamine, or a methamphetamine-heroin combination, post-deportation. For some men, reuniting with friends who were IDUs facilitated their own evolution and immediate transition as IDUs. For men who were non-injectors at the time of deportation, postdeportation stressors (e.g., lack of money, shelter, social networks) were felt to play a role in the transition into injecting practices.

Well, yes, I had lost my job, my brother's company, and everything. Well, when I was here in Tijuana, I had to come to terms with what's done is done, and there is nothing left to do. (Age 47, from Mexico City, resided in Lake Tahoe)

Several men reported that post-deportation sex partners introduced them to injected drugs, resulting in men's engagement in high-risk behaviors, including use of hit doctors and renting and sharing injection equipment, including with sex partners. In comparing their U.S. and Mexico drug use behaviors, several participants remarked that the frequency of drug use was greater or that they felt more addicted in Tijuana. Deportees often engaged in unsafe injection practices.

When a certain amount of time goes by that you haven't used heroin, you feel unwell, your body asks you for the heroin; well, I arrived at the "bordo" [area where IDUs congregate], and I did not have a syringe with which to inject myself and I had to pay so that someone would lend me their syringe... so that I could inject myself.... They are used syringes, the ones they rent. (Age 30, migrated to (Los Angeles) at age 8, has lived in Tijuana since his last deportation, 8 years ago)

Another participant reported:

If I'm with a girl that uses heroin and I do too, it depends on how much we buy, how many doses, and then with her syringe, she injects, and we inject, then we make love, but using a condom, and then we each go our separate ways... and they [the girls] have their own injection equipment and they bring new syringes and sometimes, they bring used syringes. (Age 47 from Veracruz, migrated to U.S. at age 17 , Tijuana resident since his last deportation 15 years ago)

Deportees frequently indicated that the post-deportation social, drug, and economic climates of Tijuana facilitated their drug use behaviors. For example, several men who were deported to other border cities in Mexico specifically traveled to Tijuana because they were familiar with or had heard of the local "party scene"; others had preexisting social or drug-related connections in Tijuana. The widespread availability and perceived lower cost of drugs, syringes and injection paraphernalia, and picaderos (shooting galleries), and a large local IDU community facilitated use of or a relapse to injected drugs. Deportees perceived that drug use in Mexico carried fewer consequences (vs. drug use in the United States). Yet, men also indicated that they were frequently singled out by the police for carrying clean syringes or because "track marks" (i.e., physical signs of injection behaviors, such as scars or abscesses) were visible. Targeting by police led to incarceration, during which time they received little or no medical care, experienced withdrawal symptoms, or engaged in high-risk injection behaviors 
such as sharing of injection equipment. Several men reported bingeing on drugs following their release from Tijuana's city jail.

Yes, really, try to imagine that we inject with the same needle-100 persons, I think, because there were shooting galleries, there were just two or three needles for the entire penitentiary, imagine that. (Age 36, originally from Zacatecas, came to the U.S. at age 15 , has lived in Tijuana 10 years since his last deportation)

The police planted a knife on me that I had not been carrying, but they planted it and then I got sent to the pentientiary; there, drug use was not permitted, but because I was an injection drug user, when I got out of the penitentiary, I went straight to the neighborhood and that day injected myself... and I overdosed. (Age 35, originally from Chihuahua, last deportation was 15 years ago)

\section{Deportation Impacts on Social Relationships, Well-Being, and Drug Use}

Increased drug use was identified by several participants as one mechanism for dealing with the emotional consequences of deportation (e.g., feelings of shame and resentment, trauma, loneliness, and separation from spouses/partners, parents, siblings, and children). One deportee from Nayarit who migrated at age 21 and was deported 13 years prior to the interview described the impact of deportation:

...10 years until I'm not supposed to come back to the US... when you first get out from the system, the lives you leave there, you feel kind of sad, you know, because life is kind of hard right here in Mexico, even here on the street, kind of hard, because work is hard, they pay you a little poop shit, you just have to survive. Rich people getting rich and poor people getting poorer and poorer, but that's the system. And when I was in California, it was a good time.

Several male deportees lost social and economic support from family following deportation. At the time of interview, about half of the men had limited or no contact with their families. Reasons cited for men's estrangement included families' frustration with the men's substance use behaviors, men's feelings of shame regarding substance use behaviors, or wanting to protect family members from their drug use. Several men noted that they could not return to the United States or their families until they were sober. Some men reported becoming accustomed to being alone; others described preferring their Tijuana lifestyle. The majority of participants expressed some level of remorse over decisions and behaviors which resulted in their deportation, isolation from their families, and increased drug use.

I would like to see them [my daughters] but for the same reason, I don't want them to come [to see me]... here in Tijuana it is perdition... in the street there are lots of of drug dealers, crystal [methamphetamine] and everything... they have not seen that-they have their schooling. (Age 43, originally from Veracruz, arrived in the United States at age 13, last deportation 3 years ago)

\section{DISCUSSION}

The removal of unauthorized migrants is a significant priority area for the United States and other countries, ${ }^{27}$ yet scant data exists on the relationship between deportation 
and illicit drug use. Immigrants experience multiple economic, emotional, social, and contextual stressors (e.g., access to housing) ${ }^{28-30}$ that shape their mental and physical health and access to health and social services. This pilot study provides a rare view into the pre- and post-migration substance use experiences of one cohort of male deportees. Our data illustrate the importance of social and environmental factors vis-à-vis substance use by migrant males on both sides of an international border.

Deportees reported low levels of illicit substance use as youths in Mexico; many reported initiating drug use in the United States Deportees with a history of drug use reportedly consumed "hard" drugs such as heroin, cocaine, and methamphetamine following their migration. Research in Sweden has found that substance use patterns in first and later generation immigrants is higher than among native populations, reflecting the need for youth-oriented services. ${ }^{31}$ For many deportees, U.S. drug use occurred in social situations or via relationships with other drug users. Research with migrant farm-working males in the United States has identified illicit substance use and alcohol consumption as a coping mechanism. ${ }^{21}$ Our participants also employed this strategy in dealing with disruptions in family relationships or employment conditions. Additionally, factors such as curiosity, exposure to, and the perceived widespread availability of illicit drugs in the United States reportedly played important roles in male migrants' initiation into drug use. Injection drug use in the United States was common; although participants described efforts to engage in safer injection behaviors, unsafe injection practices were prevalent. This is concerning due to the high possibility of transmission of blood-borne infections, particularly among incarcerated persons ${ }^{32}$ and circular migrants who maintain binational relationships. ${ }^{33-36}$ Drug use behaviors were perceived as changing following deportation and were attributed to factors such as individual stressors and social and environmental factors, including the pervasiveness of illicit drugs in Tijuana; ${ }^{8,9}$ unsafe injection practices persisted partially in response to environmental stressors. Shame regarding drug use reportedly affected male deportees' social relationships, particularly with family, and their self-esteem. Other research points to shame as a negative impact on substance use behaviors. ${ }^{37}$

Few deportees reported intending to return to the United States; many reported being banned from re-entry or incarceration if detected by U.S. immigration officials, reflecting their knowledge of the Immigration and Nationality Act's criteria for inadmissibility and changes to immigration policies resulting from the 1996 Illegal Immigration Reform and Immigrant Responsibility Act of $1996 .{ }^{38}$ None of our participants held immigration court documents so we cannot confirm conditions barring re-entry; however, their perceptions of potential repercussions appear to deter future migration plans. Thus, addressing the post-deportation stressors identified in our study is critical since the health status and behaviors of deportees are likely to impact resettlement communities, including Tijuana.

Our study has several limitations. It is based on interviews with a unique population of migrants (i.e., male IDU deportees) who were sampled from an observational study and were available at the time of the present study, thus, findings may not be generalizable to other classes of migrants, either from Mexico or other nations. Migration, deportation, and substance use data are based on selfreport and may be affected by recall bias, particularly among long-term Tijuana deportee residents. We cannot discern whether the study participants underwent a formal removal process via immigration courts or were repatriated to Mexico through another program. We use the term "deportee" since participants employed this term to describe their migration status and reasons for being in Mexico. We 
expect that participants felt the confidence to share sensitive migration and substance use information since the parent grant is a longitudinal study and our interviewers have been affiliated with the project for numerous years and have established a positive rapport with study participants.

The health status and health behaviors of deportees are significant issues for the United States and Mexico. The two countries share an adjacent and lengthy border $^{39}$ and a sizeable binational population that includes documented and undocumented persons. ${ }^{17,40,41}$ Identification of unauthorized immigrants in the United States is slated to remain a federal priority. ${ }^{42}$ Recent U.S. federal and state policy initiatives aim to increase the number of persons with criminal justice system records who will be repatriated to Mexico, thereby impacting the health and social resources of receiving communities in Mexico, such as Tijuana. ${ }^{27,43}$ Our study showed that injection behaviors were maintained in Mexico or initiated following deportation. Thus, greater attention to substance use behaviors among incarcerated and repatriated populations may aid in reducing substance use and transmission of blood-borne infections.

\section{CONCLUSIONS}

Our findings suggest that deportees would benefit from binational collaborations ${ }^{44}$ to reduce illicit drug use and the transmission of blood-borne infections. Early, youth-focused interventions for migrant families that foster family relationships, including parental involvement to reduce behavioral problems ${ }^{45}$ may have additional benefits for distal outcomes such as substance use and HIV risk behaviors. ${ }^{46}$ Harm reduction interventions for incarcerated and deportees may be considered by U.S entities. Additionally, the Mexican consulate-based "Ventanillas de Salud" (Health Window/Office) that are situated in the United States may refer migrants to affordable culturally and linguistically appropriate substance use and other health services for migrants. ${ }^{47,48}$

Mexico sponsors migrant-oriented programs such as the "Guía del Migrante" (Guide for Migrants), ${ }^{49}$ "Vete Sano, Regresa Sano" (Leave Healthy, Return Healthy), ${ }^{50}$ the "Manual Para la Prevención del VIH/SIDA en Migrantes Mexicanos a Estados Unidos" (Manual for Prevention of HIV/AIDS in Mexican Migrants to the U.S.), ${ }^{51}$ and the "Programa de Repatriación Humana" (Humane Repatriation Program). ${ }^{52}$ These programs may address post-deportation stressors by expanding components that address mental health concerns (e.g., depression, isolation, and transitions in family social roles) and illicit drug use. Educational programs designed for Mexican law enforcement agencies may help remove policies and practices that further fuel the HIV epidemic in Tijuana and other border communities. ${ }^{53,54}$ Finally, few substance use treatment programs are available in Mexico. ${ }^{7,55,56}$ Investments in affordable, evidence-based, and regulated substance use treatment services by Mexico, especially in border communities such as Tijuana, are needed. Our findings suggest that resettlement programs that address diverse health, social, and economic issues while also providing an official government identification form may aid deportees in shaping their post-deportation lives in Mexico.

\section{ACKNOWLEDGMENTS}

This work was funded by grants from the University of California HIV/AIDS Research Program Grant no. ID08-SD-073, the National Institute of Health 
National Institute on Drug Abuse (NIDA) 5K01DA025504-02, a UCSD Academic Senate Pilot Grant Research Award no. RI296H-OJEDA, NIDA-R01DA019829, and NIDA-T32DA023356. The authors gratefully acknowledge the contributions of study participants, binational staff and investigators from PRO-COMUSIDA, Prevencasa, Centro Nacional para la Prevención y el Control del VIH/SIDA (CENSIDA), and Instituto de Servicios de Salud de Estado de Baja California (ISESALUD).

OPEN ACCESS This article is distributed under the terms of the Creative Commons Attribution Noncommercial License which permits any noncommercial use, distribution, and reproduction in any medium, provided the original author(s) and source are credited.

\section{REFERENCES}

1. Secretaria de Salud de Mexico, Consejo Nacional Contra Las Adicciones, Insituto Nacional de Psiquiatria Ramon de la Fuente, PUblica INdS, Fundacion Gonzalo Rio Arronte I. Encuesta Nacional de Adicciones 2008. Cuernavaca, Morelos, Mexico; 2008. http://www. insp.mx/Portal/Inf/encuesta_adicciones08.php. Accessed July 20, 2010.

2. Substance Abuse and Mental Health Services Administration. Results from the 2008 National Survey on Drug Use and Health: National Findings (Office of Applied Studies, NSDUH Series H-36, HHS Publication No. SMA 09-4434). Rockville, MD; 2009.

3. Vega W, Aguilar-Gaxiola S, Andrade L, et al. Prevalence and age of onset for drug use in seven international sites: results from the International Consortium of Psychiatric Epidemiology. Drug Alcohol Depend. 2002; 68: 285-297.

4. Grant BF, Stinson FS, Hasin DS, Dawson DA, Chou SP, Anderson K. Immigration and lifetime prevalence of DSM-IV psychiatric disorders among Mexican Americans and nonHispanic Whites in the United States: results from the national epidemiologic survey on alcohol and related conditions. Arch Gen Psychiatry. 2004; 61: 1226-1233.

5. Hernandez T, Sanchez MA, Ayala L, et al. Methamphetamine and cocaine use among Mexican migrants in California: the California-Mexico epidemiological surveillance pilot. AIDS Educ Prev. 2009; 21(Supplement B): 34-44.

6. Borges G, Medina-Mora ME, Breslau J, Aguilar-Gaxiola S. The effect of migration to the United States on substance use disorders among returned mexican migrants and families of migrants. Am J Public Health. 2007; 97(10): 1847-1851.

7. Secretaria de Salud y Asistencia (SSA). Encuesta Nacional de Adicciones 2002. Mexico: Consejo Nacional Contra Las Addicciones; 2002.

8. Bucardo J, Brouwer KC, Magis-Rodriguez C, et al. Historical trends in the production and consumption of illicit drugs in Mexico: implications for the prevention of blood borne infections. Drug Alcohol Depend. 2005; 79: 281-293.

9. Brouwer KC, Case P, Ramos R, et al. Trends in the production and trafficking and consumption of methamphetamine and cocaine in Mexico. Subst Use Misuse. 2006; 41: 707-727.

10. Substance Abuse and Mental Health Services Administration. NSDUH Report: Sexually Transmitted Diseases and Substance Use. Rockville, MD; 2007.

11. Magis-Rodriguez C, Gayet C, Negroni M, et al. Migration and AIDS in Mexico: an overview based on recent evidence. J Acquir Immune Defic Syndr. 2004; 37(S4): S215S226.

12. Sanchez MA, Lemp GF, Magis-Rodriguez C, Bravo-Garcia E, Carter S, Ruiz JD. The epidemiology of HIV among Mexican migrants and recent immigrants in California and Mexico. J Acquir Immune Defic Syndr. 2004; 37(S4): S204-S214.

13. Strathdee SA, Lozada R, Ojeda VD, et al. Differential effects of migration and deportation on HIV infection among male and female injection drug users in Tijuana, Mexico. PLoS ONE. 2008; 3(7): e2690. 
14. Hagan JM, Eschbach K, Rodriguez N. U.S. deportation policy, family separation, and circular migration. International Migration Review. 2008; 42(1): 64-88.

15. Turnbull L. Life After an Illegal Immigrant is Sent Home. The Seattle Times. April 6, 2008. http://seattletimes.nwsource.com/html/nationworld/2004330685_mexicoana06m.html. Accessed July 20, 2010.

16. Harawa NT, Bingham TA, Cochran SD, Greenland S, Cunningham WE. HIV prevalence among foreign- and US-born clients of public STD clinics. Am J Public Health. 2002; 92 (12): 1958-1963.

17. Fry R. A statistical portrait of Hispanics at mid-decade. Washington, DC: Pew Hispanic Center; 2006.

18. Pew Hispanic Research Center. Mexican Immigrants in the United States: 2008. Washington, DC: Pew Hispanic Center. April 15, 2009. http://pewresearch.org/pubs/ 1191/mexican-immigrants-in-america-largest-group. Accessed July 20, 2010.

19. Passel JS, Cohn DV. A Portrait of Unauthorized Immigrants in the United States. Washington, DC: Pew Hispanic Center. April 15, 2009. http://pewresearch.org/pubs/ 1190/portrait-unauthorized-immigrants-states. Accessed July 20, 2010.

20. U.S. Department of Homeland Security. Yearbook of immigration statistics. Washington, DC: U.S. Department of Homeland Security; 2009.

21. Apostolopoulos Y, Somnez S, Kronenfeld J, Castillo E, McLendon L, Smith D. STI/HIV risks for Mexican migrant laborers: exploratory ethnographies. J Immigr Minor Health. 2006; 8(3): 291-302.

22. Heckathorn DD. Respondent driven sampling: a new approach to the study of hidden populations. Soc Probl. 1997; 44(2): 174-199.

23. Strathdee SA, Lozada-Romero R, Ojeda V, et al. Differential effects of migration and deportation on HIV infection among male and female injection drug users in Tijuana, Mexico. Mexico City, Mexico: International AIDS Conference; 2008.

24. User's Manual for Atlas.ti 5.0 [computer program]. Berlin, Germany: Atlas.ti Sicentific Software Development; 2004.

25. Onwuegbuzie AJ, Teddlie C. A framework for analyzing data in mixed methods resarch. In: Tashakkori A, Teddlie C, eds. Handbook of mixed methods in social and behavioral research. Thousand Oaks: Sage Publications; 2003: 351-383.

26. Thomas DR. A general inductive approach for analyzing qualitative evaluation data. Am J Evaluation. 2006; 27(2): 237-246.

27. U.S. Immigrations and Customs Enforcement. Secure Communities Fact Sheet. Washington, DC U.S. Immigrations and Customs Enforcement. September 1, 2009. http://www.ice.gov/ doclib/pi/news/factsheets/secure_communities.pdf. Accessed July 20, 2010.

28. Chavez LR. Shadowed lives: undocumented immigrants in American society. 2nd ed. United States: Wadsworth Thomson Learning; 1992.

29. Chiu S, Redelmeier DA, Tolomiczenko G, Kiss A, Hwang SW. The health of homeless immigrants. J Epidemiol Community Health. 2009; 63: 943-948.

30. Sundquist J, Johannson SE. The influence of exile and repatriation on mental and physical health. A population-based study. Soc Psychiatry Psychiatr Epidemiol. 1996; 31 (1): 21-28.

31. Svensson M, Hagquist C. Adolescent alcohol and illicit drug use among first- and secondgeneration immigrants in Sweden. Scand J Public Health. 2010; 38: 184-191.

32. Pollini RA, Alvelais J, Gallardo M, et al. The harm inside: injection during incarceration among male injection drug users in Tijuana, Mexico. Drug Alcohol Depend. 2009; 103 (1-2): 52-58.

33. Rachlis B, Brouwer KC, Mills EJ, Hayes M, Kerr T, Hogg RS. Migration and transmission of blood-borne infections among injection drug users: understanding the epidemiologic bridge. Drug Alcohol Depend. 2007; 90(2-3): 107-119.

34. Hirsch JS, Higgins J, Bentley ME, Nathanson CA. The social constructions of sexuality: marital infidelity and sexually transmitted disease-HIV risk in a Mexican migrant community. Am J Public Health. 2002; 92: 1227-1237. 
35. Hirsch JS, Meneses S, Thompson B, Negroni M, Pelcastre B, del Rio C. The inevitability of infidelity: sexual reputation, social geographies, and marital HIV risk in rural Mexico. Am J Public Health. 2007; 97(6): 986-996.

36. Parker A, Human Rights Watch. Forced Apart: Families and Immigrants Harmed by United States Deportation Policy. New York, NY; 2007.

37. Rhodes T, Watts L, Davies S, et al. Risk, shame and the public injector: a qualitative study of drug injecting in South Wales. Soc Sci Med. 2007; 65(3): 572-585.

38. U.S. Department of Homeland Security. INA: ACT 212 - General Classes Of Aliens Ineligible To Receive Visas And Ineligible For Admission; Waivers Of Inadmissibillity; 2009. http://www.uscis.gov. Accessed November 18, 2009.

39. U.S. Mexico Border Health Commission. Healthy border 2010: midterm review U.S. border area. El Paso: U.S. Mexico Border Health Commission; 2009.

40. Ortega AN, Fang H, Perez VH, et al. Health care access, use of services, and experiences among undocumented Mexicans and other Latinos. Arch Intern Med. 2007; 167(21): 2354-2360.

41. Fry R, Passel JS. Latino children: a majority are U.S.-born offspring of immigrants. Washington, DC: Pew Hispanic Center; 2009.

42. Preston J. Immigration Crackdown with Firings, Not Raids. New York Times. September 29, 2009. http://www.nytimes.com/2009/09/30/us/30factory.html. Accessed July 20, 2010.

43. Isackson A. Deporting Prisoners Saves State Money, Worries Baja. September 3, 2009. http://www.kpbs.org/news/2009/sep/03/headline-here. Accessed July 20, 2010.

44. Ojeda VD, Hiller SP, Estrada P. California-Mexico collaborations on social marketing campaigns targeting Mexican immigrants. Soc Mar Q. 2009; 15(4): 83-97.

45. Pantin H, Coatsworth JD, Feaster DJ, et al. Familias Unidas: the efficacy of an intervention to promote parental investment in Hispanic immigrant families. Prev Sci. 2003; 4(3): 189-201.

46. Prado G, Pantin H, Schwartz SJ, et al. A randomized controlled trial of a parent-centered intervention in preventing substance use and HIV risk behaviors in Hispanic adolescents. J Consul Clin Psychol. 2007; 75(6): 914-926.

47. Secretaria de Relaciones Exteriores de Mexico. Ventanillas de Salud. 2009. http://www. ime.gob.mx. Accessed July 20, 2010.

48. Alonso-Zaldivar R, Gorman A. Mexican Consulates Offer Healthcare Help. Los Angeles Times. May 31, 2007. http://articles.latimes.com/2007/may/31/local/me-health31. Accessed July 20, 2010.

49. Secretaria de Relaciones Exteriores de Mexico. Guia del Migrante Mexicano. Distrito Federal, Mexico; 2005. http://www.sre.gob.mx. Accessed July 20, 2010.

50. Secretaria de Salud de Mexico. Programa de Accion: Migrantes "Vete Sano, Regresa Sano.” Distrito Federal, Mexico; 2002. http://www.salud.gob.mx/docprog/estrategia_1/ migrantes.pdf. Accessed July 20, 2010.

51. Secretaria de Salud de Mexico, Centro Nacional Para la Prevencion y Control del VIH/ SIDA (CENSIDA). Manual Para la Prevencion del VIH/SIDA en Migrantes Mexicanos a Estados Unidos. Distrito Federal, Mexico; 2007. http://www.censida.salud.gob.mx/ interior/atencion.html. Accessed July 20, 2010.

52. Secretaria de Gobernacion, Insituto Nacional de Migracion. Programa de Repatriación Humana. Mexico, DF: Instituto Nacional de Migracion; 2010. http://www.inm.gob.mx/ repatriacionH/Repatriacion_H.pdf. Accessed July 20, 2010.

53. Miller CL, Firestone M, Ramos R, et al. Injecting drug users' experiences of policing practices in two Mexican-U.S. border cities: public health perspectives. Int J Drug Policy. 2008; 19(4): 324-331.

54. Strathdee SA, Magis-Rodriguez C. Mexico's evolving HIV epidemic. JAMA. 2008; 300 (5): 571-573.

55. Borges G, Wang PS, Medina-Mora ME, Lara C, Chiu WT. Delay of first treatment of mental and substance use disorders in Mexico. Am J Public Health. 2007; 97(9): 1638-1643.

56. Medina-Mora ME, Borges G, Fleiz C, et al. Prevalence and correlates of drug use disorders in Mexico. Rev Panam Salud Pública. 2006; 19(4): 265-276. 